\title{
The composition of natural waters of some source rivers of the republic of Uzbekistan, used in the thermal power engineering and the results of the experimental researches at preliminary and ion exchange treatment of water
}

\author{
R. Yusupaliev ${ }^{1}$, B.Kh. Yunusov ${ }^{1}$, M.M. Azimova ${ }^{1}$ \\ ${ }^{1}$ Tashkent State Technical University named after Islam Karimov, 100095, Uzbekistan, Tashkent, University St. 2A
}

\begin{abstract}
The article describes the possibility of use of the natural waters for generation of steam at thermal electric power stations. The chemical composition of some source rivers of the Republic of Uzbekistan is provided as well as its influence to the processing of water and contamination of the steam in the thermal energy engineering. The conditions of the preliminary chemical treatment of the natural water at TashTPP with the use of aluminum sulphate are described, as well as the experimental unit for production of the coagulant in the preliminary treatment and clarification of water; the experimental data on treatment of water with ions of chloride using the new ionites of type ASH-64 and ASH-64M, which were synthetized by the scientists of the Tashkent national university.
\end{abstract}

\section{Introduction}

The removal of the colloids and clarification of water at Tashkent thermal electric power station is performed by introduction of the technical coagulants of the aluminum sulphate $\mathrm{Al}_{2}\left(\mathrm{SO}_{4}\right)_{3}$ in to the being treated water. In connection with the impossibility of regular provision of the water treatment unit (WPU) of the TashTPP with the required agent $\mathrm{Al}_{2}\left(\mathrm{SO}_{4}\right)_{3}$, the researches are performed on production of the solution of this agent at industrial conditions.

For the deep desalting of water at TPP in the Republic of Uzbekistan, different ionites are used: KU-1, $\mathrm{KU}-2, \mathrm{AN}-17, \mathrm{AV}-18$ and others. These ionites are imported to Uzbekistan from other countries and Russia. In order to fulfill the set tasks, the study of the existing approaches on water clarification for the TPP needs was performed.

\section{Chemical composition of the natural waters of the Republic of Uzbekistan and their use at TPP}

A complex of the processes on treatment of the deeply desalted water is among the important processes of the modern TPP that provides the normed content of the mixes in the vapor and the feed water of the boilers. For this reason each TPP has a system of WPU units. The WPU system includes the units on chemical treatment of the initial water, as well as preparation of the make up water and treatment of the turbine condensate using the ionites at TPP.

In the thermal energy engineering at TPP of the Republic of Uzbekistan, in order to produce the vapor, the waters from the natural sources, like rivers, water reservoirs are mainly used. The quality of these waters is instable and depends on the components that contact the soil. The bigger content of salts in the soil, the bigger content of the mixtures in the natural water and it has good dissolving properties. There are easily and hardly dissolving mixtures in the natural water of organic and non-organic origin. The mixtures, contaminating the natural waters, are of different forms, and classification of them is provided on the pic. 1 .

Hence, the economic expenditure increases considerably during the treatment of water at TPP.

The content of ions of chloride $\mathrm{Cl}$, sulphate $\mathrm{SO}^{2-}$, nitrate $\mathrm{NO}_{3}^{-}$is observed increasing in the river water and characterize high content of salts in the water. It is required to underline that the compounds of carbon in the river water are of different forms, in the form of free carbonic acid $\mathrm{CO}_{2}$, molecular $\mathrm{H}_{2} \mathrm{CO}_{3}$ and in the form of anions $\mathrm{HCO}_{3}{ }^{-}$and $\mathrm{CO}_{3}{ }^{2-}$. The formation of the carbon compounds in the natural waters depends on the $\mathrm{pH}$ value of the service and influences the quality of water, alkali content, acidity and the carbonate hardness of water. [1]

The table 1 contains the chemical composition of the natural waters of some of the rivers of the Republic of Uzbekistan used at TPP. 
Table 1.

\begin{tabular}{|c|c|c|c|c|c|c|c|c|c|}
\hline $\begin{array}{l}\text { Che } \\
\text { mica } \\
\text { I } \\
\text { cont } \\
\text { ent }\end{array}$ & $\begin{array}{c}\text { Unit } \\
\text { of } \\
\text { msn } \\
\text { t }\end{array}$ & $\begin{array}{l}\mathbf{A} \\
\mathbf{m} \\
\mathbf{u}- \\
\mathbf{D} \\
\text { ar } \\
\text { iy } \\
\mathbf{a}\end{array}$ & $\begin{array}{l}\text { Si } \\
\text { r- } \\
\text { D } \\
\text { ar } \\
\text { iy } \\
\text { a }\end{array}$ & $\begin{array}{l}\mathbf{N} \\
\mathbf{a}- \\
\text { ri } \\
\mathbf{n}\end{array}$ & $\begin{array}{l}\text { C } \\
\text { hi } \\
\text { r- } \\
\text { ch } \\
\text { ik }\end{array}$ & 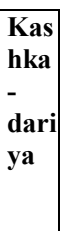 & $\begin{array}{l}\text { Sur } \\
\text { kha } \\
\text { n- } \\
\text { dari } \\
\text { ya }\end{array}$ & $\begin{array}{l}\text { Kara- } \\
\text { dariy } \\
\text { a }\end{array}$ & $\begin{array}{l}\text { Ak } \\
\text { han } \\
- \\
\text { gar } \\
\text { an }\end{array}$ \\
\hline $\begin{array}{c}\text { Non } \\
\text { al } \\
\text { hard } \\
\text { ness }\end{array}$ & $\begin{array}{l}\text { mg- } \\
\text { eq./l }\end{array}$ & $\begin{array}{l}4 . \\
3- \\
10 \\
.1\end{array}$ & $\begin{array}{l}3 . \\
8- \\
8 . \\
8\end{array}$ & $\begin{array}{l}3 . \\
0- \\
5 . \\
1\end{array}$ & $\begin{array}{l}1 . \\
8- \\
2 . \\
6\end{array}$ & $\begin{array}{l}2 . \\
8- \\
3 . \\
4\end{array}$ & $\begin{array}{l}2.0 \\
- \\
5.1\end{array}$ & $\begin{array}{l}4.1 \\
- \\
7.6\end{array}$ & $\begin{array}{l}1 . \\
5- \\
2 . \\
9\end{array}$ \\
\hline $\begin{array}{c}\mathrm{Ca} 2 \\
+\end{array}$ & $\mathrm{mg} / \mathrm{l}$ & $\begin{array}{l}60 \\
.3- \\
10 \\
9 . \\
3\end{array}$ & $\begin{array}{l}53 \\
.1- \\
87 \\
.5\end{array}$ & $\begin{array}{l}42 \\
.9- \\
62 \\
.0\end{array}$ & $\begin{array}{l}30 \\
.1- \\
39 \\
.1\end{array}$ & $\begin{array}{l}4 \\
3 . \\
1- \\
5 \\
3 . \\
7\end{array}$ & $\begin{array}{l}38 . \\
9- \\
74 . \\
4\end{array}$ & $\begin{array}{l}39.7- \\
80.1\end{array}$ & $\begin{array}{l}20 \\
.9 \\
- \\
48 \\
.4\end{array}$ \\
\hline $\mathrm{Mg}^{2+}$ & $\mathrm{mg} / \mathrm{l}$ & $\begin{array}{l}12 \\
.4- \\
36 \\
.3\end{array}$ & $\begin{array}{l}11 \\
.9- \\
54 \\
.5\end{array}$ & $\begin{array}{l}7 . \\
1- \\
23 \\
.4\end{array}$ & $\begin{array}{l}3 . \\
3- \\
9 . \\
7\end{array}$ & $\begin{array}{l}4 . \\
6- \\
1 \\
1 . \\
3\end{array}$ & $\begin{array}{l}5.4 \\
- \\
19 . \\
1\end{array}$ & $\begin{array}{l}17, \\
543 \\
, 1\end{array}$ & $\begin{array}{l}1 . \\
7- \\
4 . \\
5\end{array}$ \\
\hline $\begin{array}{c}\mathrm{Na}^{++} \\
\mathrm{K}^{+}\end{array}$ & $\mathrm{mg} / \mathrm{l}$ & $\begin{array}{l}49 \\
.2- \\
16 \\
4 . \\
2\end{array}$ & $\begin{array}{l}16 \\
.8- \\
81 \\
.5\end{array}$ & $\begin{array}{l}9 . \\
5- \\
37 \\
.1\end{array}$ & $\begin{array}{l}0, \\
8- \\
38\end{array}$ & $\begin{array}{l}0 . \\
2- \\
1 \\
2 . \\
0\end{array}$ & $\begin{array}{l}0.8 \\
- \\
12 . \\
5\end{array}$ & $\begin{array}{l}12.2- \\
5.05\end{array}$ & $\begin{array}{l}1 . \\
5- \\
7 . \\
2\end{array}$ \\
\hline $\begin{array}{l}\mathrm{Fe}^{2++} \\
\mathrm{Fe}^{3+}\end{array}$ & $\mathrm{mg} / \mathrm{l}$ & $\begin{array}{l}0 . \\
01 \\
- \\
0 . \\
04\end{array}$ & $\begin{array}{l}0 . \\
01 \\
- \\
0 . \\
04\end{array}$ & $\begin{array}{l}0 . \\
01 \\
- \\
0 . \\
04\end{array}$ & $\begin{array}{l}0 . \\
01 \\
- \\
0 . \\
05\end{array}$ & $\begin{array}{l}0 . \\
0 \\
1- \\
0 . \\
0 \\
7\end{array}$ & $\begin{array}{l}0.0 \\
1- \\
0.0 \\
7\end{array}$ & $\begin{array}{l}0.01- \\
0.05\end{array}$ & $\begin{array}{l}0 . \\
01 \\
- \\
0 . \\
04\end{array}$ \\
\hline $\begin{array}{r}\mathrm{HC} \\
- \\
\mathrm{O}^{3}\end{array}$ & $\mathrm{mg} / \mathrm{l}$ & $\begin{array}{l}10 \\
3 . \\
7- \\
16 \\
6 . \\
1\end{array}$ & $\begin{array}{l}12 \\
0- \\
18 \\
0 . \\
5\end{array}$ & $\begin{array}{l}11 \\
4- \\
17 \\
2\end{array}$ & $\begin{array}{l}97 \\
- \\
14 \\
0\end{array}$ & $\begin{array}{l}1 \\
6 \\
3 . \\
3- \\
1 \\
9 \\
5 . \\
2\end{array}$ & $\begin{array}{l}90 . \\
2- \\
192 \\
.2\end{array}$ & $\begin{array}{l}134 \\
-- \\
220\end{array}$ & $\begin{array}{l}62 \\
.8 \\
- \\
13 \\
6 . \\
6\end{array}$ \\
\hline $\begin{array}{l}\text { SO } \\
2- \\
4\end{array}$ & $\mathrm{mg} / \mathrm{l}$ & $\begin{array}{l}11 \\
2 . \\
9- \\
23 \\
7 . \\
2\end{array}$ & $\begin{array}{l}10 \\
2 . \\
5- \\
33 \\
3\end{array}$ & $\begin{array}{l}47 \\
.7- \\
19 \\
.5\end{array}$ & $\begin{array}{l}10 \\
- \\
15 \\
, 7\end{array}$ & $\begin{array}{l}4 . \\
4- \\
7 . \\
0\end{array}$ & $\begin{array}{l}30 \\
0- \\
93 \\
9\end{array}$ & $\begin{array}{l}101 \\
,- \\
210\end{array}$ & $\begin{array}{l}7 . \\
6- \\
20 \\
.0\end{array}$ \\
\hline Cl- & $\mathrm{mg} / \mathrm{l}$ & $\begin{array}{l}58 \\
.5- \\
24 \\
2 . \\
2\end{array}$ & $\begin{array}{l}15 \\
.6- \\
51 \\
.1\end{array}$ & $\begin{array}{l}9 . \\
2- \\
32 \\
2 . \\
6\end{array}$ & $\begin{array}{l}3 . \\
1- \\
4 . \\
5\end{array}$ & $\begin{array}{l}1 . \\
8- \\
3 . \\
9\end{array}$ & $\begin{array}{l}2.2 \\
- \\
10 . \\
0\end{array}$ & $\begin{array}{l}12 . \\
8- \\
28\end{array}$ & $\begin{array}{l}1 . \\
4- \\
3 . \\
6\end{array}$ \\
\hline $\begin{array}{c}\mathrm{NO} \\
- \\
3\end{array}$ & $\mathrm{mg} / \mathrm{l}$ & $\begin{array}{l}0 . \\
09 \\
- \\
1 . \\
98 \\
\end{array}$ & $\begin{array}{l}0 . \\
15 \\
- \\
10\end{array}$ & $\begin{array}{l}0 . \\
04 \\
- \\
0 . \\
99\end{array}$ & $\begin{array}{l}0 . \\
1- \\
09 \\
9\end{array}$ & $\begin{array}{l}0 . \\
9- \\
3 . \\
0\end{array}$ & $\begin{array}{l}0.0 \\
3- \\
8.1\end{array}$ & $\begin{array}{l}0.9 \\
-10\end{array}$ & $\begin{array}{l}0 . \\
5- \\
2 . \\
1\end{array}$ \\
\hline $\mathrm{pH}$ & $\mathrm{mg} / \mathrm{l}$ & $\begin{array}{l}7 . \\
9- \\
8 . \\
9 \\
\end{array}$ & $\begin{array}{l}7 . \\
6- \\
8\end{array}$ & $\begin{array}{l}7 . \\
6- \\
88 \\
.3\end{array}$ & $\begin{array}{l}7 . \\
6- \\
8 . \\
1 \\
\end{array}$ & $\begin{array}{l}8 . \\
1- \\
8 . \\
4\end{array}$ & $\begin{array}{l}8.0 \\
- \\
8.3\end{array}$ & $\begin{array}{l}7.4 \\
- \\
8.0\end{array}$ & $\begin{array}{l}7 . \\
5- \\
8 . \\
8\end{array}$ \\
\hline $\begin{array}{c}\text { Oxy- } \\
\text { da- } \\
\text { tion }\end{array}$ & $\mathrm{mg} / \mathrm{l}$ & $\begin{array}{l}0 . \\
7- \\
1 . \\
9 \\
\end{array}$ & $\begin{array}{l}0 . \\
7- \\
1 . \\
1 \\
\end{array}$ & $\begin{array}{l}0 . \\
5- \\
1 . \\
9 \\
\end{array}$ & $\begin{array}{l}0 . \\
4- \\
15\end{array}$ & $\begin{array}{l}0 . \\
7- \\
1 . \\
6\end{array}$ & $\begin{array}{l}0.4 \\
- \\
1.5\end{array}$ & $\begin{array}{l}0.7 \\
- \\
1.5\end{array}$ & $\begin{array}{l}0 . \\
3- \\
1 . \\
3 \\
\end{array}$ \\
\hline
\end{tabular}

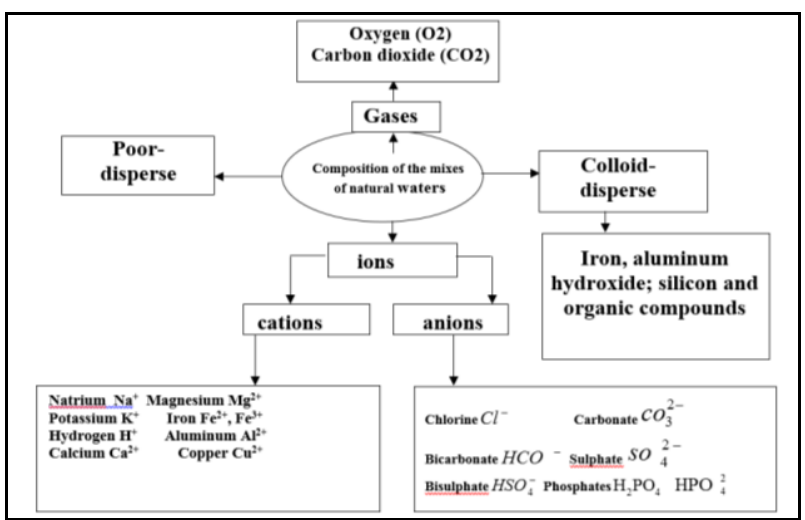

Fig. 1. Classification of mixtures of natural waters.

As seen from the table 1 the widely spread compounds of the natural waters of the Republic of Uzbekistan are mainly compounds of calcium $\mathrm{Ca}$ and magnesium $\mathrm{Mg}$, the percentage composition of which sharply changes during the year.

Dependence of composition of different forms of carbon compounds from $\mathrm{pH}$ index is provided on the picture 2 .

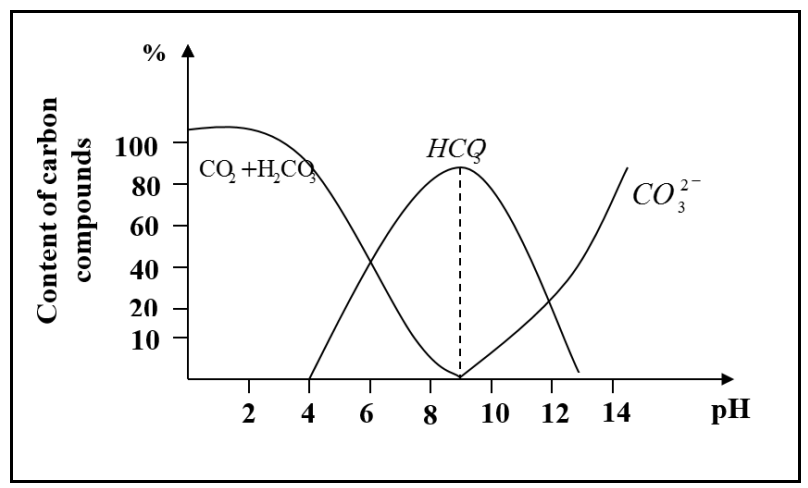

Fig. 2. Dependence of composition of carbon compounds from $\mathrm{pH}$ level.

As seen from the diagram, in the case of increase of $\mathrm{pH}$ of water from 3 to 12 the degree of molecular dissociation of the carbonic acid: $\left(\mathrm{H}_{2} \mathrm{CO}_{3}\right)$, and at $\mathrm{pH}$ from 1.0 to $4.5-95 \%$ of the carbonic acid practically is in the type of molecules in non-dissociation form.

At $\mathrm{pH}$ from 8.5 to 14 the dissociation of the bicarbonate anions increases: $\mathrm{HCO}_{3}{ }^{-} \rightarrow \mathrm{H}^{+}+\mathrm{CO}_{3}{ }^{2-}$ with formation of carbonate ion $\mathrm{CO}_{3}{ }^{2-}$. It is required to underline that in order to produce the vapor in the steam boilers, the $\mathrm{pH}$ of the feed water shall be within 9-10.5 (1). In this conditions the carbon acid compounds in the feed water of the steam boilers can be in the form of carbon ions $\mathrm{CO}_{3}{ }^{2-}$.

In the operating service, when the temperature of the heat medium $>$ is $200^{\circ} \mathrm{C}$, the formation of the hardly dissolvable compounds on the inner surfaces of the steam boilers occur in the form of calcium of carbonate

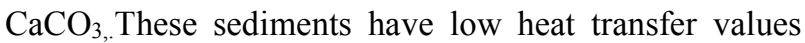
(0.6-0.7 W/mK), impact the heat exchange between the metal and the operating medium. This leads to the increase of the temperature of the inner surface of the boiler, consumption of fuel and speed of the corrosion process on the surface of the heater. These processes lead to the emergencies, capacity decrease of the boiler 
and impairment of the modes of normative operation in the TPP.

The silicone compounds, similar to the carbon acid compounds are also present in the natural waters in different forms: molecular $\mathrm{nSiO}_{2} \cdot \mathrm{mH}_{2} \mathrm{O}, \mathrm{H}_{2} \mathrm{SiO}_{3}$ and in the form of anions $\mathrm{HSiO}_{3}{ }_{3}, \mathrm{SiO}_{3}{ }^{2-}$. The form of formation of the silocone compounds in the natural water also depends on the $\mathrm{pH}$ value.

At $\mathrm{pH}$ from 6 to $8-9 \%$ of the molecules of $\mathrm{H}_{2} \mathrm{SiO}_{3}$ dissociate with formation of $\mathrm{HSiO}_{3}{ }^{-}$, and the rest in the type of molecules of $\mathrm{H}_{2} \mathrm{SiO}_{3}$ or in the colloid condition $\mathrm{nSiO}_{2} \cdot \mathrm{mH}_{2} \mathrm{O}$. When $\mathrm{pH}$ is bigger than 8 , the silicone compounds, present in the natural water, mainly are in the type of $\mathrm{HSiO}_{3}{ }^{-}$and partially as $\mathrm{SiO}_{3}{ }^{-2}$. In this way, the bigger the content of the silicone in the steam water, the bigger the contamination of the vapor with the silicone compounds. It is caused by the silicone compounds positive temperature rate of dissolution both in water and in the vapor[2].

Hence the bigger content of the silicone compounds in the boiler water, the bigger possibility of contamination of the vapor in the result of steam generation of the boiler water.

The contamination of vapor with the mixes of the silicone compounds form the insolvable sediments in the wheel space of the turbine that push the corrosion and erosion processes. The insolvable silicone sediments mainly consists of the iron oxides, zinc, copper, silicone acid, calcium compounds, magnesium and aluminum. In the composition of the sediment there are sulfates, chlorides, silicates, carbonates, sodium phosphates and even sodium hydroxide. The increase of such sediments pushes the corrosion of the metal, especially in the side of LPC. All types of sediments in the steam turbines decrease their capacity, limit the nominal power of the turbine.

Based on the above mentioned it is obvious that to increase the reliability of the operation and economy of the thermal equipment of the thermal power plants, it is required to provide the feed of the steam boilers with highly desalted and silicone free water.

In relation to this, the treatment of the natural waters to produce the vapor at all TPP of the Republic of Uzbekistan is implemented in two stages: at the first stage the reagent treatment such as the coagulation and liming and the second stage the deep desalting by thermal and ionite treatment of the water.

The economic expenditure at deep desalting of the water at TPP depends on many factors: quality of the initial water, selection of the methods and used reagents. At ionite treatment - the type of the used ionites and technologies of the ionite treatment of water.

\section{Electrocoagulation technology for production of coagulant at TashTPP}

In the WTU of the Tashkent TPP the component is the preliminary treatment of water from silt and different organic contaminants. The preliminary treatment is in clarification of the initial water (Boz-su canal) by removing the coarsely dispersed contaminants.
At the present time the clarification of water at TashTPP is done by method of coagulation which is the introduction of the special coagulant of the aluminum sulphate $\left(\mathrm{AI}_{2}\left(\mathrm{SO}_{4}\right)_{3}\right)$ into the being treated water.

Due to the impossibility of regular provision of the WTU of TashTPP with the required reagent - the aluminum sulphate. To solve the problem, the electrocoagulation technology is proposed for produce the aluminum hydroxide during the preliminary treatment and clarification of the water.

This technology provide high efficiency of the treatment of water and possesses the advantages compared with the reagent methods such as compactness, absence of huge reagent station, simple maintenance, possibility of complete automation and low capital expenditures.

The researches showed that the coagulant, produced by electrochemical method, possesses with the bigger sorption capacity than the aluminum hydroxide formed as a result of hydrolysis of its salts. The later can be explained with the special conditions of formation of the coagulating structures in the electrolysis, as well as lower influence of the anions of the strong acids the concentration of which, in this case, is lower than the one during the introduction of the chemical reagents into the water [3].

The essence of the electrocoagulation method is in the anodic dissolution of the metals under the influence of the electric current with further formation of the colloid mixtures.

In the being developed technology, it is proposed to use the aluminum and duraluminum wastes.

This technology of production of the coagulant was introduced for operation. It diagram is provided on the fig. 3 .

The consumption of the electric energy can be minimized by selecting the inter-electrode intervals and the time of commutation of the electrodes. The calculations, based on the experience at pilot unit on production of the coagulant by electrochemical method, showed that the capacity of the unit at the density of the current at electrodes is $50 \mathrm{~A} / \mathrm{m} 2$ and the temperature of the electrolyte is $20^{\circ} \mathrm{C}$ and equates to $101 /$ hour. The capacity of the unit can be regulated by the density of the current, as well as the temperature of the electrolyte.

The produced coagulant with the required composition is accumulated in the coagulant tank (available at TashTPP). From this tank the coagulant through the dosing unit is mixed with the initial water (water from Boz-su) and is fed to the inlet of the clarification column.

To better the process of treatment and clarification, the being treated water is added with the acid to receive the required $\mathrm{pH}$. The $\mathrm{pH}$ detectors, installed at the inlet and outlet of the clarification column, and the control diagram of the dosing unit, regulate the supply of the required volume of the acid through the dosing unit. 


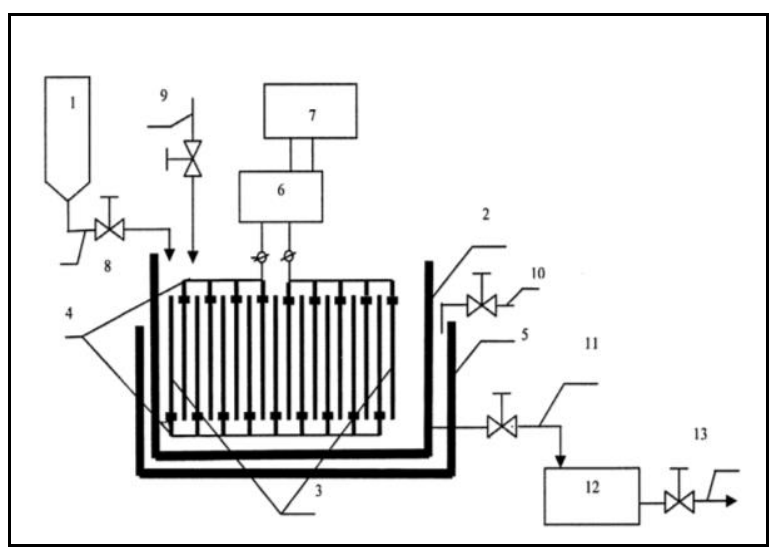

Fig. 3. The diagram of the pilot unit of production of the coagulant at TashTPP.

1-metering tank for the acid; 2-coagulant tank; 3-aluminum plates; 4-connecting buses; 5-cooling tank; 6-ballast resistance; 7- power source; 8-acid supply piping; 10-cooling water supply piping; 11-ready coagulant drain piping; 12-coagulant tank; 13supply of coagulant to the water treatment line.

The implementation of the proposed project is justified by the pilot sample of the electrocoagulator, that showed its operability. The produced coagulant on this unit, completely satisfies the requirements of the treatment and clarification of the initial water. The calculations, based on the experience of the operation on the pilot unit on production of the coagulant by electrochemical method, showed that the productivity of the proposed unit at the density of the current at electrodes of $50 \mathrm{~A} / \mathrm{m} 2$ and temperature of the electrolyte of $20^{\circ} \mathrm{C}$ equates to $201 /$ hour of coagulant with the chemical composition: density $1.3 \mathrm{gr} / \mathrm{cm} 3$; oxidation of aluminum $\mathrm{Al}_{2} \mathrm{O}_{3}-7,6 \%$; in conversion to the aluminum sulphate $\mathrm{Al}_{2}\left(\mathrm{SO}_{4}\right)_{3}-25,5 \%$. The capacity of the unit can be regulated by the density of the current, as well as the temperature of the electrolyte.

The mass consumption of the substances used for coagulation is decreased 2.5-3 folds compared to the reagent coagulation.

Based on the results of the researches on this unit, we proposed and approved with TashTPP the sketch design. "Development of the highly efficient automated electrocoagulation technology of preliminary treatment and clarification of the water at TashTPP".

\section{The research of the ion-exchange capabilities of the new ionites}

One of the reliable methods of preparation of the deep desalting of water for the feed of the steam generators of TPP is the ionite treatment of water. Hence during the preparation of the make up water and cleaning of the turbine condensate at TPP, the big amount of synthetic ionites is required. [4].

At the present time, the National University of Uzbekistan proposed a technological regulation of production of the new ion-exchange materials on the base of the polyacrylonitrile, polyacrylamide, that are produced by the Navoiy checmial combinate. The successful synthesis of the pilot lot of the samples of ion- exchange materials of the type ASH-64 and ASH-64M was performed.

These ionites were received by modification of the polyacrylonitrile, produced at the Navoiy chemical combinate through the polymerization.

The synthesized ionites of the type ASH-64 and ASH-64M are resistant to the influence of the $4 \%$ solution of the salt acid and fully preserve the absorption ability within the range of the temperatures of 660degr.C and above.

The preliminary experimental researches showed, that the ionites ASH-64 and ASH-64M successfully clean the water from the ionites of the chlorine as a result of the following reaction:

\section{$\mathrm{RIOH}+\mathrm{Cl}^{-}=\mathrm{RICI}+\mathrm{OH}-$}

The tables show the results of the experiment researches of the ion-exchange ability of the ionites ASH-64 and ASH-64M against the ions of the chlorine.

As can be seen from the results of the research, the $\mathrm{Cl}$ ions are well absorbed on ionites ASH-64 and ASH$64 \mathrm{M}$, however, with the increase of the content of the ions in the being treated water, the volume of the carried water before the breakthrough of the chlorine decreases. It is related to the size of the exchange capacity of the ionites. The values of the nominal exchange capacit of the ionites mainly differs from the quantity of the introduced functional groups such as the primary ($\mathrm{NH} 2)$, secondary $(=\mathrm{NH})$ and tertiary $(=\mathrm{N})$ amine group. The more there are such tied amine groups in the received ionites, the bigger value of the ion-exchange ability (E). [5].

Table 2. The results of the research of the ion-exchange ability of the ionite ASH-64 in the water with the content of the chlorine ions of $10 \mathrm{mg} / 1$ is shown in the table 2 .

\begin{tabular}{|c|c|c|c|}
\hline $\begin{array}{c}\text { Volume of } \\
\text { the } \\
\text { carried } \\
\text { water, ml. }\end{array}$ & $\begin{array}{c}\text { Volume } \\
\text { of } \\
\text { NaOH } \\
\text { consum } \\
\text { ed for } \\
\text { the } \\
\text { titratin } \\
\text { g, ml. }\end{array}$ & $\begin{array}{c}\text { The residual } \\
\text { content of the } \\
\text { chlorine ions in } \\
\text { the filter cake } \\
\text { where the } \\
\text { initial content } \\
\text { of the chlorine } \\
\text { is 10 mg/l. }\end{array}$ & $\begin{array}{c}\text { Residual } \\
\text { equivalent } \\
\text { content of } \\
\text { chlorine ions } \\
\text { mgeq/l. }\end{array}$ \\
\hline 200 & 0 & 0 & 0 \\
\hline 400 & 0 & 0 & 0 \\
\hline 1500 & 0 & 0 & 0 \\
\hline 2500 & 0 & 0 & 0 \\
\hline 5000 & 0 & 0 & 0 \\
\hline 6300 & 0 & 0 & 0 \\
\hline 6350 & 0.1 & 0.8 & 0.02 \\
\hline 6400 & 0.15 & 0.18 & 0.06 \\
\hline 6450 & 0.20 & 2.7 & 0.07 \\
\hline 6500 & 0.30 & 4.7 & 0.12 \\
\hline 6550 & 0.35 & 5.4 & 0.15 \\
\hline 6000 & 0.40 & 6.3 & 0.17 \\
\hline
\end{tabular}




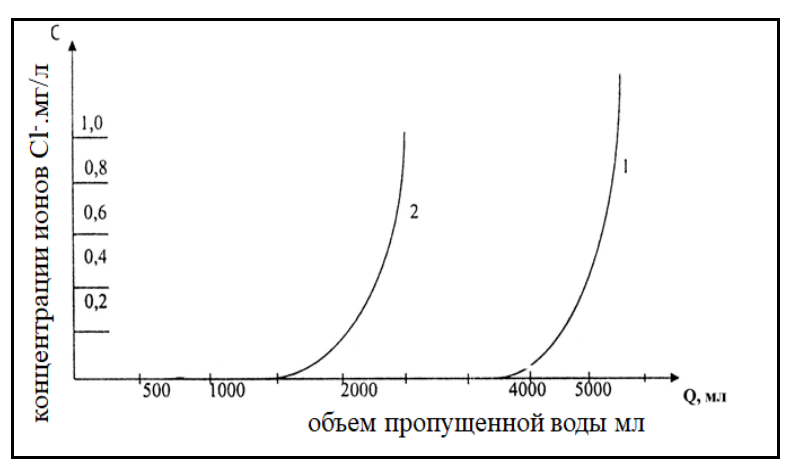

Fig. 4. Absorption of the chlorine ions on ionites ASH-64 and ASH-64M with content of the chlorine in the being studied water of $1-10 \mathrm{mg} / 1,2-36 \mathrm{mg} / 1$.

Table 3. The results of the research of the ion-exchange ability of the ionite ASH-64M in the water with the content of the chlorine ions is $36 \mathrm{mg} / \mathrm{l}$.

\begin{tabular}{|l|l|l|l|}
\hline $\begin{array}{l}\text { Volume } \\
\text { of the } \\
\text { carried } \\
\text { water, } \\
\text { ml. }\end{array}$ & $\begin{array}{l}\text { Volume of } \\
\text { NaOH } \\
\text { consumed } \\
\text { for the } \\
\text { titrating, ml. }\end{array}$ & $\begin{array}{l}\text { The residual } \\
\text { content of the } \\
\text { thlorine ions } \\
\text { in the filter } \\
\text { cake where } \\
\text { the initial } \\
\text { content of the } \\
\text { chlorine is } \\
\text { 36mg/l. }\end{array}$ & $\begin{array}{l}\text { Residual } \\
\text { equivalent } \\
\text { content of } \\
\text { chlorine } \\
\text { ions } \\
\text { mgeq/l. }\end{array}$ \\
\hline 200 & 0 & 0 & 0 \\
\hline 400 & 0 & 0 & 0 \\
\hline 600 & 0 & 0 & 0 \\
\hline 750 & 0 & 0 & 0 \\
\hline 800 & 0.3 & 4.5 & 0.12 \\
\hline 850 & 0.4 & 6.3 & 0.17 \\
\hline 900 & 0.5 & 8.1 & 0.22 \\
\hline 950 & 0.6 & 9.9 & 0.27 \\
\hline 1000 & 0.8 & 13.5 & 0.36 \\
\hline 1050 & 1.1 & 18.5 & 0.51 \\
\hline 1100 & 1.7 & 29.7 & 0.81 \\
\hline 1150 & 2.1 & 36.9 & 1.01 \\
\hline
\end{tabular}

The experimental results of adsorption of the chlorine ions on ionites of type ASH-64 with content of the chlorine 10.20 and $36 \mathrm{mg} / \mathrm{l}$ is shown on the picture.

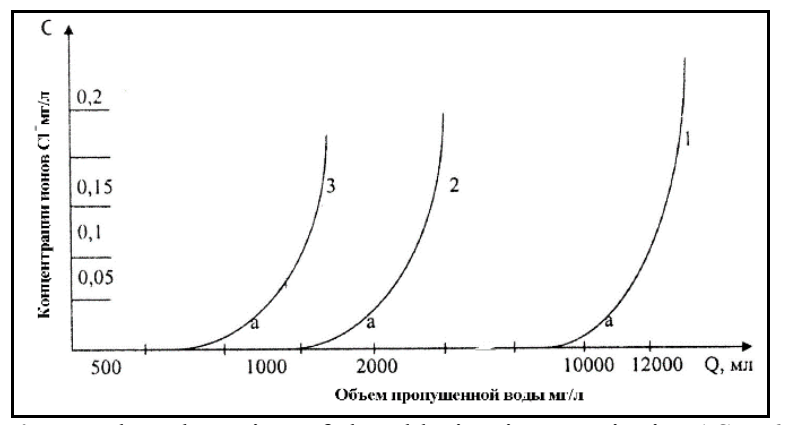

Fig. 5. The adsorption of the chlorine ions on ionite ASH-64 with content of $1-10 \mathrm{mg} / 1,2-20 \mathrm{mg} / 1,3-36 \mathrm{mg} / 1$ of chlorine in the being studied water.

The value $E_{p}$ against chlorine ions is calculated on the formula $\mathrm{mgr}$ eq/m:

$\mathrm{E}_{\mathrm{p}}=\left(\mathrm{C}_{\text {исх. }}-\mathrm{C}_{\Phi}\right) \times \mathrm{Q} / \mathrm{m}$

where $\mathrm{C}_{\text {исд.- }}$ concentration of chlorine ions in the being studied water, $\mathrm{mg} / \mathrm{l}$.
$\mathrm{C}_{\phi^{-}}$concentration of chlorine ions in the filter cake, $\mathrm{mg} / \mathrm{l}$.

Q- volume of the being filtered water before the breakthrough of chlorine ions, $\mathrm{ml}$.

$\mathrm{m}$ - consumption of $\mathrm{NaOH}$ solution, $\mathrm{ml}$.

As a result, the experimental researches on study of the adsorption of ionites ASH-64 and ASH-64M showed, that these ionites can be used during the treatment of the anions of strong acids, such as chlorine, sulphate and nitrate, hence these ionites can be used at water processing units of TPP.

\section{Conclusion}

At TPP to produce vapor, the deep cleaned desalted water is required. Hence the economical consumption during preparation of water at TPP depends on the following factors: chemical composition of the initial water, capacity of the units, used reagents and types of ionite materials during the processing of the water.

At TashTPP the technical aluminium sulphate with the clearance of $65-70 \%$ is used in the preliminary treatment of water for the elimination of the colloido-disperse substances. By using it, the formation of the sludge compounds and consumption of the reagent increases dramatically.

Hence, we have developed the economical electrocoagulating technology on production of the required reagent using the aluminum wastes as the electrodes. Also the experimental results of the ionexchange ability of the new ionites ASH-64, ASH-64M against the chlorine ions are provided. The results of the research showed that the indicated ionites well absorb the chlorine ions.

\section{References}

1. Lifchits O.F. "Reference book on water treatment of the boiler units" M.Pub. Energy, 1986.

2. Guseva O.V. Physico-chemical bases of calculation of the water-chemical modes of the heat networks and evaporators.- M, MEI. 2001. -48 p.

3. Yusupaliev R.M. , Usmonov N.O. "Pilot electrocoagulating unit of the preliminary treatment of the natural water" Energy preservation energy engineering energy audit No.10 (152), Moscow, 2016.

4. Kopilov A.S., Ochkov V.F. Water treatment in the energy engineering. M. MEI. 2006.

5. Yusupaliev R.M Study book "Control of the water treatment techniques and use of the chemical agents in the Heat energy engineering". Tashkent, 2013. 